\title{
The never-ending problem of Miocene beaver taxonomy
}

Isaac Casanovas-Vilar and David M. Alba

Acta Palaeontologica Polonica 56 (1), 2011: 217-220 doi: http://dx.doi.org/10.4202/app.2010.0051

The finds of Miocene beavers are not rare at all. Nevertheless, in most localities these rodents are only represented by a few dental elements, so that large collections are only occasionally available to researchers. Hence, the description of sufficiently large samples, such as the recently published description of Steneofiber depereti from Hambach 6C (NW Germany, MN5) by Mörs and Stefen (2010), deserves the greatest attention. After a comprehensive description and comparison of the material, these authors conclude that previous citations of the beaver Chalicomys jaegeri from the MN4 to MN6 (early to middle Miocene) are misidentifications of the genus Steneofiber. Following Stefen (2009), these authors further question the validity of all the known Chalicomys species from the later middle Miocene $(\mathrm{MN7+8)}$. We agree with these authors that the occurrence of $C$. jaegeri in the middle Miocene is doubtful, but we disagree with their arguments for the synonymization of several species. Here we address this point and discuss the taxonomic criteria for distinguishing both genera, further reviewing the taxonomy of the genus Chalicomys at the species level.

Isaac Casanovas-Vilar [isaac.casanovas@icp.cat] and David M. Alba [david.alba@icp.cat], Institut Català de Paleontologia (ICP), Mòdul ICP, Campus de la UAB, 08193 Cerdanyola del Vallès, Barcelona, Spain.

This is an open-access article distributed under the terms of the Creative Commons Attribution License (for details please see creativecommons.org), which permits unrestricted use, distribution, and reproduction in any medium, provided the original author and source are credited. 